
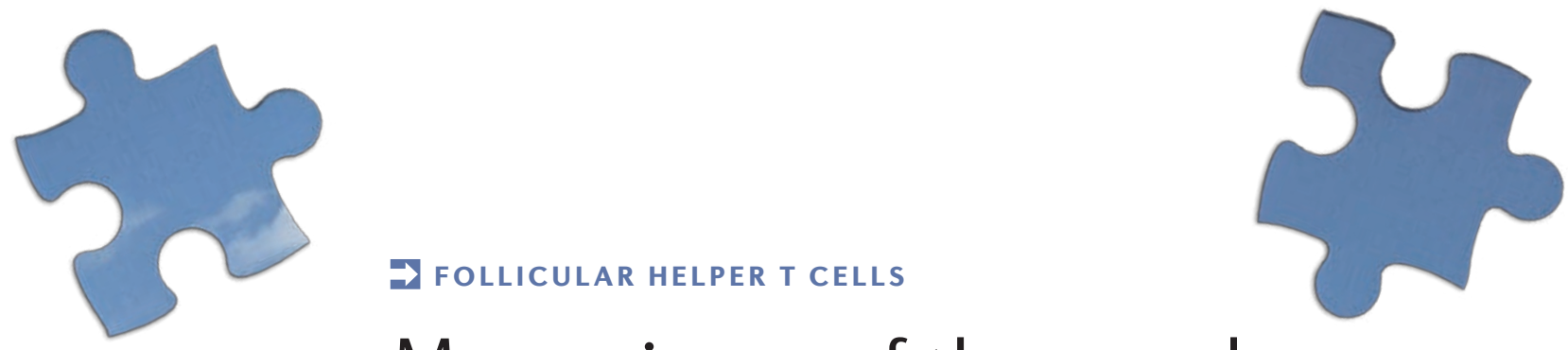

\title{
More pieces of the puzzle
}

Follicular helper $\mathrm{T}\left(\mathrm{T}_{\mathrm{FH}}\right)$ cells are a subset of $\mathrm{CD}^{+} \mathrm{T}$ cells that are confined to the B-cell areas of lymphoid organs and have a role in the selection of memory B cells or long-lived plasma cells that produce high-affinity antibodies. Now, three papers have

broadened our understanding of $\mathrm{T}_{\mathrm{FH}}$ cells, describing features of their functional development, their role in shaping antibody responses and how their dysfunction contributes to systemic autoimmunity.

In the first study, Fazilleau et al. examined the total antigen-specific $\mathrm{T}_{\mathrm{H}}$-cell compartment in the draining lymph nodes following protein vaccination. The antigen-specific $\mathrm{T}_{\mathrm{H}}$ cells could be divided into three subsets: a T-zone-restricted B-lymphocyteinduced maturation protein 1 (BLIMP1)-expressing 'lymphoid' $\mathrm{T}_{\mathrm{H}}$-cell subset $\left(\mathrm{CD} 6 \mathrm{~L}^{\text {hi }} \mathrm{CXCR} 5^{\text {low }}\right.$ ), an 'emigrant' $\mathrm{T}_{\mathrm{H}}$-cell subset (CD62L $\left.\mathrm{L}^{\text {low }} \mathrm{CXCR} 5^{\text {low }}\right)$ and a 'resident' $\mathrm{T}_{\mathrm{H}}$-cell subset $\left(\mathrm{CD} 62 \mathrm{~L}^{\text {low }} \mathrm{CXCR} 5^{\text {hi }}\right.$ ) that uniquely expressed B-cell lymphoma 6 (BCL6) and had other

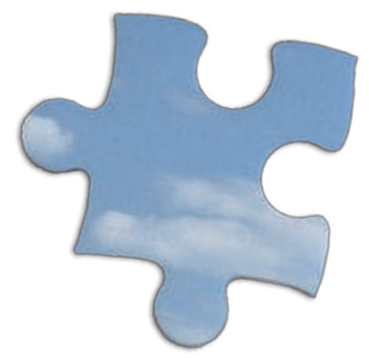
features of $\mathrm{T}_{\mathrm{FH}}$ cells. The authors then determined the relationship between the development of these $\mathrm{T}_{\mathrm{H}}$-cell subsets and the affinity and diversity of their T-cell receptors (TCRs). They found that naive $\mathrm{CD} 4^{+} \mathrm{T}$ cells that expressed TCRs with high affinity for antigen preferentially developed into $\mathrm{T}_{\mathrm{FH}}$ cells. In addition, these $\mathrm{T}_{\mathrm{FH}}$ cells had the strongest peptide-MHC class II binding and a more restricted TCR repertoire compared with the lymphoid or emigrant $\mathrm{T}_{\mathrm{H}}$ cells. So, the strength of TCR binding is causally linked to the development of antigen-specific $\mathrm{T}_{\mathrm{FH}}$ cells in vivo.
In the second study, Reinhardt and colleagues sought to determine the exact role for $\mathrm{T}_{\mathrm{H}}$-cell-derived cytokines in the selection of high-affinity antibodies and the induction of class switching in $\mathrm{B}$ cells. In response to infection, all interleukin-4 (IL-4)-producing $\mathrm{T}$ cells in the draining lymph nodes were restricted to the B-cell follicles and germinal centres and had a $\mathrm{T}_{\mathrm{FH}}$-cell phenotype. These IL-4-producing $\mathrm{T}_{\mathrm{FH}}$ cells were phenotypically and functionally distinct from IL-4-producing $\mathrm{T}_{\mathrm{H}} 2$ cells in the periphery. Further investigation showed that some $\mathrm{T}_{\mathrm{FH}}$ cells formed conjugates with B cells undergoing immunoglobulin class switching; IL-4-producing $\mathrm{T}_{\mathrm{FH}}$ cellB-cell conjugates contained IgG1 transcripts, whereas interferon- $\gamma$ producing $\mathrm{T}_{\mathrm{FH}}$-cell-B-cell conjugates contained IgG2a transcripts. In addition, $\mathrm{T}_{\mathrm{FH}}$-cell-derived IL-4 was shown to be specifically required for the generation of high-affinity IgG1 antibodies. This study therefore shows that the production of cytokines by $\mathrm{T}_{\mathrm{FH}}$ cells shapes the isotype and affinity of the antibody response. In the third study, Linterman et al. determined the role of $\mathrm{T}_{\mathrm{FH}}$ cells in systemic lupus erythematosus (SLE) using Roquin ${ }^{\text {san } / s a n}$ mice (roquin is a RING-type ubiquitin ligase that regulates mRNA stability in T cells). These mice develop a spontaneous SLE-like autoimmune disease with features that include autoantibody production, spontaneous germinal centre formation and high numbers of
$\mathrm{T}_{\mathrm{FH}}$ cells. The expansion of $\mathrm{T}_{\mathrm{FH}}$ cells and the spontaneous formation of germinal centres were shown to be the result of a $\mathrm{T}_{\mathrm{FH}}$-cellintrinsic defect in these mice. Deletion of SLAM-associated protein (SAP; required for germinal centre formation) in these mice resulted in a selective reduction in the number of $\mathrm{T}_{\mathrm{FH}}$ cells, but not other $\mathrm{T}_{\mathrm{H}}$ cells, and abrogated the spontaneous formation of germinal centres and the production of autoantibodies. By contrast, $\mathrm{T}_{\mathrm{FH}}$ cells isolated from Roquin ${ }^{\text {san/san }}$

mice induced spontaneous germinal centre formation in wild-type mice. So, expansion of the $\mathrm{T}_{\mathrm{FH}}$-cell population and defective positive selection of germinal centre B cells has a role in the development of autoimmunity, possibly owing to reduced competition between $\mathrm{B}$ cells for T-cell help.

Together, these three papers provide us with a considerable advancement in our understanding of the differentiation and function of $\mathrm{T}_{\mathrm{FH}}$ cells.

Olive Leavy

ORIGINAL RESEARCH PAPERS Fazilleau, N. et al. The function of follicular helper $T$ cells is regulated by the strength of $\mathrm{T}$ cell antigen receptor binding. Nature Immunol. 1 Mar 2009 (doi:10.1038/ni.1704)| Reinhardt, R. L., Liang, H.-E. \& Locksley, R. M. Cytokine-secreting follicular T cells shape the antibody repertoire. Nature Immunol. 1 Mar 2009 (doi:10.1038/ni.1715) Linterman, M. A. et al. Follicular helper T cells are required for systemic autoimmunity. J. Exp. Med. 16 Feb 2009 (doi:10.1084/jem.20081886) 